\title{
Comparison of minimum support price scheme for maize and paddy in north Karnataka
}

\author{
K.N. ASHARANI, C. MURTHY AND M.S. KISHORE
}

Received : 10.08.2016; Revised : 22.08.2016; Accepted : 09.09.2016

\begin{abstract}
MSP is a form of market intervention by the Government of India to insure agricultural producers against any sharp fall in farm prices to protect the producer- farmers- against excessive fall in price during bumper production years. The study was conducted during the year 2015-16 using the secondary data pertaining to the MSP for different crops and open market prices for paddy and maize in selected markets of Uttara Kannada and Belagavi districts. Compound growth rate were computed to comprehend the annual growth in MSP of agricultural commodities for the period from 2000-01 to 2015-16. It is revealed that the annual growth rate for MSP for all commodities were found to be positive.The growth rate of MSP for paddy and maize were 8.26 per cent and 8.62 per cent, respectively.The increase in MSP was not equitable to all the crops. Both open market prices and MSP had shown increasing trend but most of the years, open market prices for paddy and maize both were higher than the MSP in all the selected markets of UttaraKannada and Belagavi districtsand the percentage differences were not high. The influence of MSP on market price was not significant in paddy and maize. Hence, there is need to bring some improvement in the price policy to different crops for ensuring highest returns to the farmers to continue their production with the increase in cost of inputs especially the crops like paddy and maize.
\end{abstract}

KEY WORDS : Minimum support price, Paddy, Maize, APMC, Uttara Kannada, Belagavi

How to cite this paper: Asharani, K.N., Murthy, C. and Kishore, M.S. (2016). Comparison of minimum support price scheme for maize and paddy in north Karnataka. Internat. J. Com. \& Bus. Manage, 9(2) : 179-187. DOI: 10.15740/HAS/IJCBM/9.2/179-187.

\section{MEMBERS OF THE RESEARCH FORUM}

Correspondence to:

K.N. ASHARANI, Department of Agribusiness Management, College of Agriculture, University of Agricultural Sciences, DHARWAD (KARNATAKA) INDIA

Email: asharanikn3@gmail.com

\section{Authors' affiliations:}

C. MURTHY AND M.S. KISHORE, Department of Agribusiness Management, College of Agriculture, University of Agricultural Sciences, DHARWAD (KARNATAKA) INDIA

Email: cmurthy1966@gmail.com ; nabuta127@gmail.com 